\author{
Ewa Cieślik* \\ Katarzyna Nawrot**
}

\title{
POTENCJAL GOSPODARCZY AFRYKI ZACHODNIEJ: WYBRANE IMPLIKACJE Z ANALIZY TAKSONOMICZNEJ DLA EKSPANSJI GOSPODARCZEJ
}

\section{Wprowadzenie}

Rozważania w artykule koncentrują się na wielowymiarowym badaniu potencjału gospodarczego krajów regionu Afryki Zachodniej w celu sformułowania rekomendacji zarówno dla polityki gospodarczej krajów europejskich, jak i dla przedsiębiorców z Europy co do kierunków podjęcia współpracy z omawianymi krajami. Gospodarki obszaru zachodnioafrykańskiego cechuje znaczne zróżnicowanie pod względem poziomu rozwoju społeczno-gospodarczego oraz środowiska prowadzenia działalności gospodarczej. W celu oceny ich potencjału gospodarczego zbadano poziom i dynamikę najważniejszych mierników makroekonomicznych, przepływy handlowe i kapitałowe oraz przeanalizowano wskaźniki obrazujące warunki prowadzenia działalności gospodarczej w tych krajach. Przeprowadzona analiza pozwoliła zidentyfikować kraje zachodnioafrykańskie, które w długim okresie mogą okazać się szczególnie perspektywiczne dla europejskiego biznesu. Jednakże, mając na względzie spore zacofanie regionu, wskazano na wiele wyzwań i problemów stojących przed rządami poszczególnych krajów. Problemy rozwojowe występujące w większości państw zachodnioafrykańskich stanowią poważne bariery dla budowania odpowiednich warunków do prowadzenia działalności gospodarczej, stąd intensyfikacja współpracy z omawianymi krajami w znacznej mierze będzie zależała od wyeliminowania tych przeszkód.

Podejmowane w artykule badania mają za zadanie pogłębić wiedzę dotyczącą potencjału gospodarczego państw Afryki Zachodniej w kontekście ewentualnych możliwości i ograniczeń współpracy gospodarczej z tym regionem. Kwestia tych

* Wydział Gospodarki Międzynarodowej, Uniwersytet Ekonomiczny w Poznaniu.

** Wydział Gospodarki Międzynarodowej, Uniwersytet Ekonomiczny w Poznaniu. 
Zagadnień staje się niezwykle ważna w odniesieniu do rosnącej roli kontynentu afrykańskiego w gospodarce światowej i nadal niskiego poziomu kooperacji z omawianym $w$ artykule regionem. W literaturze przedmiotu odczuwalna jest luka poznawcza w zakresie procesów rozwojowych krajów Afryki Zachodniej i możliwości nawiązania współpracy $z$ wybranymi państwami tego regionu. W występujących nielicznie opracowaniach eksperckich nie poddaje się kompleksowej analizie poszczególnych regionów oraz nie przeprowadza się badań mających na celu wskazanie najkorzystniejszych kierunków geograficznych dla współpracy gospodarczej z Afryką. Stąd przeprowadzona $w$ artykule analiza $w$ pewnym stopniu przyczynia się do wypełnienia tych braków w literaturze przedmiotu. Natomiast zaprezentowane w artykule badanie stanowi jeden z etapów pogłębionej oceny potencjału gospodarczego krajów Afryki Zachodniej.

Na potrzeby prowadzonej analizy w artykule przyjęto podział Afryki zaproponowany przez Organizację Narodów Zjednoczonych. Tym samym w badaniu Afryki Zachodniej uwzględniono szesnaście krajów regionu, mianowicie: Benin, Burkinę Faso, Gambię, Ghanę, Gwineę, Gwineę Bissau, Liberię, Mali, Mauretanię, Niger, Nigerię, Republikę Zielonego Przylądka, Senegal, Sierra Leone, Togo oraz Wybrzeże Kości Sloniowej.

W artykule podjęto próbę osiągnięcia następujących celów:

1) oceny potencjału gospodarczego oraz skonstruowania, $z$ wykorzystaniem metod taksonomicznych, rankingu gospodarek zachodnioafrykańskich ze względu na panujące w nich warunki prowadzenia biznesu;

2) sformułowania rekomendacji dla kierunków i charakteru ekspansji europejskich przedsiębiorstw na rynki Afryki Zachodniej.

Podstawę źródłową badania stanowiły informacje pochodzące $z$ wtórnych baz danych organizacji międzynarodowych, m.in. dane Banku Światowego, World Economic Forum, Programu Narodów Zjednoczonych ds. Rozwoju (UNDP) czy Heritage Foundation. Okres badawczy koncentruje się głównie na roku 2014, co wynikało z trudności w pozyskiwaniu nowszych danych dla wielu analizowanych państw.

Artykuł podzielono na cztery części, wprowadzenie i konkluzje. W pierwszej części scharakteryzowano region Afryki Zachodniej z wykorzystaniem wybranych miar obrazujących potencjał gospodarczy oraz warunki prowadzenia biznesu. W drugiej zaprezentowano zastosowaną metodę badawczą oraz scharakteryzowano uwzględnione w analizie dane. Trzecią część artykułu stanowi omówienie rezultatów badania. Natomiast w ostatniej części na podstawie przeprowadzonej analizy taksonomicznej podjęto próbę sformułowania rekomendacji dla kierunków polityki gospodarczej krajów europejskich oraz strategii przedsiębiorstw w stymulowaniu ekspansji na rynki omawianych krajów afrykańskich. 


\section{Przegląd podstawowych wskaźników makroekonomicznych, internacjonalizacji i warunków prowadzenia działalności gospodarczej}

Pod względem najważniejszych wskaźników makroekonomicznych i demograficznych Afrykę Zachodnią należy uznać za region bardzo nierównomiernie rozwinięty oraz wykazujący oznaki zacofania gospodarczego. Wiele państw zachodnioafrykańskich zaliczanych jest do najbiedniejszych na świecie. Wszystkie kraje regionu, z wyjątkiem Mauretanii, należą do Wspólnoty Gospodarczej Państw Afryki Zachodniej (Economic Community of West African States, ECOWAS). Ponadto wszystkie państwa ${ }^{1}$ pozostają członkami Unii Afrykańskiej. Natomiast Nigeria jako jedyna przynależy od 1972 r. do Organizacji Krajów Eksportujących Ropę Naftową (Organization of the Petroleum Exporting Countries, OPEC). Proces integracji w Afryce Zachodniej podlega poważnym ograniczeniom ze względu na niestabilność polityczną i konflikty występujące w regionie (np. Burkina Faso, Gwinea, Gwinea Bissau, Liberia, Sierra Leone, Wybrzeże Kości Słoniowej). Generalnie, kraje analizowanego obszaru są klasyfikowane w rankingach rozwoju na najniższych pozycjach na świecie. Zgodnie z podziałem opracowywanym przez Bank Światowy większość państw Afryki Zachodniej należy do grupy krajów o niskim dochodzie per capita, tylko Republika Zielonego Przylądka, Wybrzeże Kości Słoniowej, Ghana, Mauretania, Nigeria i Senegal znajdują się w gronie państw o niższym średnim dochodzie na osobę. Jednocześnie Afryka Zachodnia charakteryzuje się wysokim przyrostem naturalnym, a około $40 \%$ społeczeństwa stanowią osoby poniżej 25 . roku życia ${ }^{3}$.

Analizując wielkość generowanego PKB, można zauważyć, że Afrykę Zachodnią zdominowała gospodarka nigeryjska (ponad 78\% PKB regionu i 52\% populacji, obok RPA i Kenii najważniejszy rynck w $\Lambda$ fryce), którą próbują doścignąć gospodarki Ghany, Wybrzeża Kości Słoniowej oraz Senegalu. Średnioroczny wzrost ekonomiczny dla całego regionu w 2014 r. wyniósł 5,79\%, jednak kilka gospodarek (m.in. Burkina Faso, Wybrzeże Kości Słoniowej, Gambia, Ghana, Liberia, Nigeria czy Sierra Leone) przekroczyło ten pułap ${ }^{4}$. Zachwianie tempa wzrostu gospodarczego wynikało głównie

1 Tylko Burkina Faso zostala na krótko zawieszona w czlonkostwie w 2015 r. Stanowiło to konsekwencję przeprowadzonego we wrześniu $2015 \mathrm{r}$. zamachu stanu zorganizowanego przez zwolenników obalonego w 2014 r. prezydenta Compaoré. African Union, 2015, http://www.au.int/

2 WDI, World Development Indicators, World Bank Database, 2015.

3 Population Reference Bureau, 2013 World Population Data Sheet, 2015, http://www.prb.org/Publications/Datasheets/2013/2013-world-population-data-sheet/world-map.aspx\%23map/world/population/2013 [dostęp 12.10.2015].

4 UNCTAD, UNCTAD Database, 2016, www.unctad.org [dostęp 12.02.2016]. 
z niestabilności politycznej, kryzysu instytucjonalnego i niepokojów społecznych z nimi związanych w niektórych krajach, np. Nigerii, Mali czy Gwinei Bissau. Wzrost ekonomiczny w Afryce Zachodniej stymulują głównie konsumpcja, produkcja ropy naftowej i gazu ziemnego oraz wydobycie innych minerałów. W mniejszym stopniu za wzrost w regionie odpowiadają inwestycje. Najszybciej rozwijającą się gospodarką regionu w 2014 r. pozostawało Sierra Leone, którego wzrost stymulował głównie eksport rud żelaza oraz rozwój sektorów budowlanego i rolnego. Gospodarki wielu krajów regionu nadal w sporej mierze opierają się na ekstensywnym rolnictwie: do nawet 70,7\% udziału w PKB w przypadku Liberii i 47,1\% w przypadku Togo. Najbardziej rozwiniętymi rynkami wewnętrznymi w regionie charakteryzują się Nigeria i Ghana ${ }^{5}$. Analizując najbardziej rozwinięte branże w gospodarce regionu, widać, że dominuje działalność związana $z$ wytwarzaniem nisko przetworzonych dóbr - branże związane $z$ wydobyciem surowców i ich przetwarzaniem. Tylko w Beninie, Burkina Faso, Republice Zielonego Przylądka i Gambii bardziej od przemysłu wydobywczego rozwinęło się rolnictwo ${ }^{6}$.

W zakresie wzrostu PKB per capita w 2014 r. średnia dla Afryki Zachodniej $(2,94 \%)$ została przekroczona przez kilka państw (m.in. Burkina Faso, Wybrzeże Kości Słoniowej, Mauretanię i Sierra Leone). W przypadku niektórych krajów, chociażby Gwinei, Gwinei Bissau i Mali obserwowano nawet spadki w poziomie PKB na osobę. Najwyższe wartości PKB per capita występowały w Republice Zielonego Przylądka, natomiast najniższą wartością tego miernika charakteryzował się w $2014 \mathrm{r}$. Niger, którego PKB per capita pozostawało prawie 9-krotnie niższe od PKB na osobę w Republice Zielonego Przylądka. Najważniejsza gospodarka regionu - Nigeria charakteryzuje się drugą w omawianym regionie wielkością PKB przypadającego na osobę ${ }^{7}$.

Dynamicznemu wzrostowi PKB i PKB per capita w krajach Afryki Zachodniej towarzyszy pogłębianie się nierówności dochodowych. Afryka Zachodnia plasuje się w grupie najmnicj egalitarnych pod względem dystrybucji dochodów narodów w świecie ${ }^{8}$. Około $60 \%$ ludności zamieszkującej Afrykę Zachodnią zyje za mniej niż 2 USD dziennie . Ponadto około połowę ludności zachodnioafrykańskiej stanowią

5 Nigerię cechuje nadal słabe nasycenie rynku produktami i producentami, stąd konkurencja pozostaje na znacznie niższym poziomie niż np. w RPA, a możliwa jest realizacja efektu skali. Rosnący odsetek ludności zamieszkującej miasta oraz wzrost liczebności klasy średniej i osób bogatych podnoszą atrakcyjność rynku. Obecnie supermarkety realizują około $1 \%$ sprzedaży detalicznej w kraju, a resztę sprzedaży - nieformalne sklepy. AT Kearney, FDI Confidence Index, 2015, https://www.atkearney.com/ [dostepp 11.10.2015].

6 AfDB et al., African Economic Outlook 2015. Regional development and spatial inclusion, OECD Publ., Paris 2015.

7 UNCTAD, UNCTAD Database, op.cit.

8 CIA Factbook, 2015, https:/www.cia.gov/library/publications/resources/the-world-factbook/ [dostęp 11.12.2015].

9 AfDB et al., op.cit. 
kobiety, w większości wykluczone z podejmowania decyzji nie tylko dotyczących spraw publicznych, lecz także wpływających na ich własne zycie ze względu na obowiązujące w regionie normy społeczne, wysoki poziom ubóstwa, niskie wykształcenie, a najczęściej jego zupełny brak.

Biorąc pod uwagę kompleksowe wskaźniki rozwoju społeczno-gospodarczego, np. HDI, prawie wszystkie kraje Afryki Zachodniej, poza Ghaną i Republiką Zielonego Przylądka, znajdują się w grupie państw o niskim poziomie rozwoju społecznego. Tylko Ghanę i Republikę Zielonego Przylądka sklasyfikowano jako kraje o średnim poziomie rozwoju społecznego ${ }^{10}$.

Gospodarki krajów afrykańskich w dużej mierze opierają swój potencjał na bogactwach naturalnych, zarówno rolnych, jak i mineralnych. Klimat i zachodnioafrykańska roślinność powodują, że wiele produktów rolnych dominuje w lokalnej konsumpcji i eksporcie państw regionu ${ }^{11}$. Afryka Zachodnia jest również znaczącym producentem minerałów, chociażby takich jak złoto (Burkina Faso, Wybrzeże Kości Słoniowej, Ghana $^{12}$, Gwinea, Liberia, Sierra Leone i Mali), diamenty (Ghana, Gwinea, Burkina Faso, Liberia i Sierra Leone) ${ }^{13}$ czy rudy metali. Region również znany jest z wydobycia ropy naftowej, a głównym producentem surowca pozostaje Nigeria. W Gabonie, Wybrzeżu Kości Słoniowej, a ostatnio w Ghanie także wydobywa się ten surowiec ${ }^{14}$.

Stopy bezrobocia w państwach Afryki Zachodniej, poza Mauretanią i Senegalem, kształtują się poniżej średniej dla całego kontynentu (9\%). Jednakże przy ich analizie należy zachować ostrożność, gdyż w tych krajach istnieje ukryte bezrobocie i zatrudnienie w sektorze nieformalnym. Szczególnie poważnym problemem pozostaje bezrobocie wśród osób młodych ${ }^{15}$. Region nie był w stanie skorzystać $\mathrm{z}$ renty demograficznej, gdyż wzrosty tamtejszych gospodarek nie kreują w szybkim tempie nowych miejsc pracy ${ }^{16}$.

W zakresie polityki fiskalnej trudno dopatrywać się jednolitej tendencji w krajach Afryki Zachodniej. Część państw prowadzi racjonalną politykę budżetową, starając się utrzymywać deficyt budżetowy na niskim poziomie, jednak przed większością analizowanych krajów (Republika Zielonego Przylądka, Gambia czy Ghana) ciągle stoi wyzwanie redukcji deficytów budżetowych. Z deficytem budżetowym powiązane

${ }_{10}$ UNDP, Human Development Reports, 2015, http://hdr.undp.org/en/2015-report [dostęp 20.1 1.2015].

11 D. Seck, Accelerated economic growth in West Africa, Springer, Dakar 2015.

12 Kraj jest drugim w Afryce po RPA producentem złota. Kopalnie złota w kraju należą przede wszystkim do zagranicznych spółek z Wielkiej Brytanii, Chin oraz RPA.

13 Tylko diamenty pochodzące z Sierra Leone można uznać za dobrej jakości. Najważniejszym graczem na rynku diamentów w regionie pozostaje grupa De Beers.

14 U.S. Geological Survey, 2015, http://www.usgs.gov/ [dostęp 22.12.2015].

15 H. Cleveland, Youth unemployment in West Africa, „Borgen Magazine” 16, 2014.

16 USAID, EADS Economic Trends Reports: West Africa, 2013. 
jest zadłużenie krajów Afryki Zachodniej. Najwyższy poziom długu publicznego w relacji do PKB w 2014 r. generowały Republika Zielonego Przylądka i Mauretania ${ }^{17}$. Poza Republiką Zielonego Przylądka, Nigerią i Gwineą wszystkie kraje regionu zaliczane są przez Bank Światowy do grupy Najbardziej Zadłużonych Państw Świata (HIPC). Kraje Afryki Zachodniej, będąc jednymi $z$ najuboższych na świecie, stały się ważnymi beneficjentami ODA (Official Development Assistance) ${ }^{18}$.

Gospodarki Afryki Zachodniej charakteryzują się umiarkowaną otwartością na handel zagraniczny. Jednocześnie spada udział regionu w światowym handlu zagranicznym. Eksport Afryki Zachodniej spadt z 2\% w 1980 r. do 0,7\% w 2014 r. Podobnie przedstawia się kwestia importu - w badanym okresie zmalał z 1,2\% do $0,6 \%$. Udział regionu w afrykańskim eksporcie w 2014 r. wyniósł niewiele ponad $25 \%$, a w imporcie $18,6 \%$. Dynamika eksportu Afryki Zachodniej po 2007 r. wyraźnie przyspieszyła. Najważniejszymi partnerami handlowymi krajów regionu są: Unia Europejska, inne kraje afrykańskie, Chiny, USA i Indie. Handel zagraniczny Afryki Zachodniej wyraźnie zdominowała Nigeria, która realizowała ponad 67\% eksportu i prawie 51\% importu regionu w 2014 r. Cała Afryka Zachodnia uzyskuje od lat spore nadwyżki w bilansie obrotów bieżących, szczególnie na rachunku handlowym ${ }^{19}$. Jednak nadwyżki te są wyłącznie zasługą eksportu nigeryjskiego, gdyż pozostałe kraje regionu notują deficyty na swoich rachunkach bieżących. Najwyższe deficyty od lat ma Ghana ${ }^{20}$. Wskaźniki terms of trade dla regionu pozostają bardzo zróżnicowane. W 2014 r. najwyraźniejszą poprawę warunków handlu zanotowały Wybrzeże Kości Słoniowej i Ghana. Z kolei znaczne pogorszenie terms of trade notowano w przypadku Liberii. Najniższy wskaźnik terms of trade w 2014 r. obserwowano w Sierra Leone. Ponadto był on jednym $z$ najniższych na świecie ${ }^{21}$.

Kraje zachodnioafrykańskie uzależniły swój eksport od wąskiej grupy surowców rolnych i mineralnych, przez co ich gospodarki stały się bardzo wrażliwe na zmiany cen tych bogactw na rynkach światowych. Około $85 \%$ dóbr eksportowanych przez omawiane kraje zalicza się do surowców i opartych na nich półproduktach ${ }^{22}$. Eksport regionu w 2014 r. oszacowano na 140 mld USD, z czego większość (około 72\%) przypadało na ropę naftową i gaz. Pozostałymi ważnymi dobrami sprzedawanymi przez

\footnotetext{
17 Kraj stara się redukować dług przez stopniową jego spłatę i negocjacje $z$ wierzycielami w celu umorzenia części długów; World Bank, IBRD, IDA, The World Bank Data, 2015, http://data.worldbank.org/indicator [dostęp 17.11.2015]; OECD, OECD Statistics, 2015, http://stats.oecd.org/ [dostęp 16.11.2015]; AfDB et al., op.cit.

18 Global Economy and Development at Brookings, 2015, Private capital flows, official development assistance, and remittances to Africa: Who gets what?

19 Tylko w 2011 r. wystąpił niewielki deficyt handlowy; UNCTAD, UNCTAD Database, op.cit.

20 Ibidem.

21 World Bank, World Bank Database, 2015.

22 World Integrated Trade Solutions, 2015, http://wits.worldbank.org [dostęp 17.11.2015].
} 
$\Lambda$ frykę Zachodnią za granicę pozostawały: złoto $(6,4 \%)$, ziarno kakaowca $(5,2 \%)$, rudy żelaza $(1,4 \%)$ oraz bawełna (1\%). Największym eksporterem regionu pozostaje wspomniana wcześniej Nigeria. Za nią uplasowały się: Ghana (udział w eksporcie zachodnioafrykańskim 9,4\%) oraz Wybrzeże Kości Słoniowej (8,7\%). O bardzo nierównomiernie rozkładającym się eksporcie w omawianym regionie świadczy fakt, iż udział pozostałych 14 krajów w eksporcie wynosi tylko 14\%. Najważniejszymi kierunkami eksportu Afryki Zachodniej w 2014 r. były: Brazylia, Unia Europejska, USA, Japonia, Indie i Korea Południowa ${ }^{23}$.

W przypadku importu kraje Afryki Zachodniej charakteryzują się mniejszą aktywnością. Na koniec 2014 r. wartość sprowadzanych do nich towarów wyniosła 118,3 mld USD. Importowano głównie ropę naftową (16\%), statki i barki $(5,8 \%)$, platformy wiertnicze $(5,2 \%)$, samochody osobowe $(3 \%)$, ryż $(2,5 \%)$, leki $(1,9 \%)$, pszenicę $(1,8 \%)$, samochody ciężarowe $(1,5 \%)$, telefony $(1,2 \%)$, ryby $(1,1 \%)$, cement oraz cukier (po 1\%). W $2013 \mathrm{r}$. produkty zaawansowane technologicznie stanowily 3,01\% wartości importu regionu. Ważnymi importerami omawianego regionu, poza wspomnianą wcześniej Nigerią, były również Ghana (12,3\%), Wybrzeże Kości Słoniowej $(9,4 \%)$ oraz Senegal $(5,5 \%)$. Głównymi rynkami importowymi pozostawały Chiny, USA, Unia Europejska, Korea Południowa i Indie ${ }^{24}$.

Pozycja Afryki Zachodniej w globalnych łańcuchach wartości jest niska. Region wyprzedza Afrykę Środkową i Wschodnią pod względem partycypacji w łańcuchach wartości ( $14 \%$ udział w łańcuchach wartości w całej $\Lambda$ fryce) i znacznie odbiega od Afryki Południowej, będącej na kontynencie liderem w zakresie udziału w powiązaniach produkcyjnych ze światem. Tylko Ghana oraz w mniejszym stopniu Mauretania nieznacznie przekraczają w tym zakresie średnią dla kontynentu afrykańskiego. Rynek zachodnioafrykański powiązany jest przede wszystkim $z$ łańcuchami dostaw $\mathrm{w}$ Europic oraz $\mathrm{w}$ trochę mniejszym stopniu $\mathrm{z}$ azjatyckimi łańcuchami wartości. Nie bez znaczenia dla osiągania niskich pozycji przez analizowane kraje w powiązaniach produkcyjnych pozostają wysokie koszty handlu zagranicznego, szczególnie w Nigrze, Liberii i Burkina Faso. W przypadku krajów bez dostępu do morza wysokie koszty handlu są częściowo uzasadnione. Jednak wszystkie analizowane kraje borykają się z niską jakością dróg, taboru kolejowego, opóźnieniami w transportach oraz nisko rozwiniętym systemem wspierania wymiany handlowej, co przejawia się m.in. w skomplikowanych procedurach celnych, portowych czy odwoławczych, braku harmonizacji przepisów i dokumentacji handlowej, czy tė̇ korupcji ${ }^{25}$.

23 Ibidem; AfDB et al., op.cit.

24 World Integrated..., op.cit.; AfDB et al., op.cit.; World Bank, World Bank Database, op.cit.

25 WEF, 2015, http://www.weforum.org/ [dostęp 17.11.2015]. 
Afryka Zachodnia staje się coraz ważniejszym odbiorcą BIZ na kontynencie. W 2014 r. do regionu napłynęly inwestycje w wysokości 12,8 mld USD, co dawało obszarowi drugie miejsce wśród regionów kontynentu: $23,7 \%$ udział w napływach BIZ do Afryki. Do 2014 r. Afryka Zachodnia przyciągnęla prawie $152 \mathrm{mld}$ USD w formie BIZ, co dawało jej 21\% udział w skumulowanych BIZ kontynentu. W latach 2007-2014 średnioroczna stopa wzrostu napływu BIZ do regionu wynosiła $14 \%{ }^{26}$. Najwięcej BIZ do końca 2014 r. napłynęło do Nigerii (86,7 mld USD), Ghany (23,2 mld USD) oraz Wybrzeża Kości Słoniowej (7,7 mld USD). Zagraniczni inwestorzy praktycznie zupełnie omijają Gwineę Bissau czy Gambię.

Afryka Zachodnia to marginalny inwestor zagraniczny. Do 2014 r. udział odpływów BIZ $z$ regionu generowal niewiele ponad $8 \%$ skumulowanych BIZ z całego kontynentu i wynosił 17,8 mld USD. Średnioroczne tempo wzrostu wartości odpływającego $\mathrm{Z}$ regionu kapitału w formie BIZ w latach 2007-2014 było wysokie i wynosiło około 30\%. Do 2014 r. najwięcej BIZ za granicą ulokowały Nigeria (10,3 mld USD) oraz Liberia $(4,3 \text { mld USD })^{27}$.

Nigeria, Senegal, Ghana i Mauretania powołały w ostatniej dekadzie narodowe wehikuły inwestycyjne zarządzające rezerwami walutowymi powstałymi $z$ nadwyżek wpływów pochodzących ze sprzedaży surowców, głównie ropy naftowej. Największym funduszem dysponuje Nigeria. Sovereign Investment Authority Excess Crude Oil Account zarządza aktywami o wartości 8 mld USD, co daje funduszowi drugie miejsce po Angoli w $\Lambda$ fryce Subsaharyjskiej ${ }^{28}$.

Afryka Zachodnia należy do regionów świata o niskim poziomie konkurencyjności międzynarodowej. Świadczą o tym chociażby mierniki wydajności pracy znacznie odbiegające od średniej produktywności na świecie (około 32,5 tys. USD). Jednak wskaźniki wzrostu wydajności pracy w większości państw regionu przewyższają średnią dla $\Lambda$ fryki Subsaharyjskiej. Jednym z niewielu wyjątków pozostaje Nigeria. Na przestrzeni ostatnich 5 lat Nigeria notowała nieznaczne przyrosty w zakresie poprawy produktywności pracy. Poza typowymi determinantami tego zjawiska, tj. niskim poziomem edukacji czy inwestycji, należy wskazać na jeszcze jedną przyczynę spadku wydajności. W Nigerii obserwowane jest zjawisko nadwyżki podaży pracy nad zapotrzebowaniem na pracowników ${ }^{29}$.

Pod względem wskaźnika konkurencyjności opracowywanego przez World Economic Forum, Ghana i Senegal pozostawały najbardziej atrakcyjnymi gospodarkami

26 UNCTAD, UNCTAD Database, op.cit.

27 Ibidem.

28 E. Cieślik, African Sovereign Wealth Funds: Facts and figures, „Gospodarka Narodowa” Iss. 6, 2014; SWF Institute, 2015, http://www.swfinstitute.org/ [dostęp 11.10.2015].

29 World Bank, World Bank Database, op.cit. 
analizowanego regionu (miejsca 111 i 112), podczas gdy pozostałe państwa znajdują się w grupie najmniej konkurencyjnych na świecie ${ }^{30}$. Te dwa kraje znajdują się także najwyżej z państw regionu pod względem wskaźnika KEI, jednak poziom rozwoju gospodarki opartej na wiedzy pozostaje niski. Na niski poziom innowacyjności omawianego regionu wskazuje również ranking Global Innovation Index, w którym najwyżej uplasował się Senegal (4 miejsce w regionie subsaharyjskim i 84 na świecie) ${ }^{31}$. Pozostałe państwa zostały bardzo nisko ocenione pod względem innowacyjności, z czego w tej kategorii Togo zajęło przedostatnie miejsce $w$ świecie ${ }^{32}$. Na niskim poziomie pozostają także publiczne wydatki poczynione na edukację w tych krajach ${ }^{33}$.

Raporty „Doing Business” najwyżej pod względem łatwości prowadzenia działalności gospodarczej plasują Ghanę. Najniżej w raportach Banku Światowego plasują się Gwinea Bissau, Liberia i Mauretania. Kraje te nie tylko cechują się najmniej przychylnym warunkami do rozwoju przedsiębiorczości w regionie, lecz także zamykają globalny ranking ${ }^{34}$.

Środowisko prowadzenia biznesu w znacznej mierze wiąże się z poziomem wolności gospodarczej panującej w danym kraju. Pod tym względem w regionie zachodnioafrykańskim najlepiej prezentują się Republika Zielonego Przylądka i Ghana, które przynależą do grupy gospodarek o umiarkowanej wolności gospodarczej. Pozostałe kraje klasyfikowane są jako w większości bez wolności gospodarczej oraz represjonowane. Najgorzej pod względem braku skrępowania działalności prezentują się te same kraje, które zamykają ranking „Doing Business”35.

Wysokie pozycje w rankingach percepcji korupcji też ważą na postrzeganiu Afryki Zachodniej przez zagranicznych inwestorów ${ }^{36}$. W zestawieniu Ibrahim Index of African Governance najwyżej oceniono Republikę Zielonego Przylądka (2 miejsce po Mauritiusie), która w ostatnich 15 latach dokonała znacznych usprawnień w zakresie udziału społeczeństwa w sprawowaniu władzy, rządów prawa oraz infrastruktury. Najniżej w rankingu uplasowała się Gwinea, w której chociaż prawie wszystkie elementy indeksu brane pod uwagę w zestawieniu poprawily się, to kraj nadal nisko oceniono ze względu na jakość zarządzania publicznego ${ }^{37}$. Kraje Afryki

\footnotetext{
30 WEF, op.cit.

31 World Bank, World Bank Database, op.cit.

32 Johnson Cornel University, INSEAD, WIPO, The Global Innovation Index 2015.

3 AfDB et al., op.cit.

34 IFC, The World Bank, Doing Business Report 2014, Washington, D.C. 2014.

35 Zadne $z$ państw regionu nie znajduje się $w$ grupie krajów represjonowanych. Heritage Foundation, 2015, http://www.heritage.org [dostęp 14.03.2015).

36 Transparency International, 2015, http:/www.transparency.org/cpi2014/results [dostęp 14.03.2015].

37 Ibrahim Forum, 2013 Ibrahim Forum Facts \& Figures, Africa ahead: The next 50 years, Mo Ibrahim Forum Foundation, Addis Abeba, November 2013.
} 
Zachodniej często są pomijane w światowych rankingach atrakcyjności ze względu na brak szczegółowych danych potrzebnych do ewaluacji tych państw $w^{38}$.

\section{Dyskusja zmiennych w analizie i opis metody badania}

W ocenie warunków prowadzenia biznesu w Afryce Zachodniej szczególnie przydatne okazują się metody wielowymiarowej analizy porównawczej, które pozwalają na zbudowanie miary syntetycznej zastępującej opis obiektów za pomocą wielu wskázników statystycznych. Stąd w artykule podjęto próbę oceny potencjału gospodarczego i warunków do prowadzenia działalności gospodarczej, a w rezultacie klasyfikacji poszczególnych krajów, stosując bezwzorcowe metody. Bezwzorcowa klasyfikacja obiektów należy do metod wielowymiarowej analizy danych, zajmującej się badaniem obiektów scharakteryzowanych wieloma cechami. Informacje o przedmiotach badania umieszczane zostają w macierzy obserwacji. Wybór metod bezwzorcowych $\mathrm{w}$ poniższym badaniu wynika $\mathrm{z}$ trudności wskazania krajów, mogących służyć za model do naśladowania dla zróżnicowanych krajów zachodnioafrykańskich. Trudno również o zadowalający wzorzec pochodzący z kontynentu afrykańskiego, a z kolei wskazanie modelu wśród krajów rozwiniętych, np. Stany Zjednoczone czy wybrany kraj Europy Zachodniej, oraz przyrównywanie do niego państw Zachodnioafrykańskich byłoby wysoce dyskusyjne ${ }^{39}$.

W celu oceny potencjału gospodarczego oraz warunków prowadzenia biznesu w poszczególnych krajach Afryki Zachodniej wybrano następujące zmienne diagnostyczne:

1) $X_{1}$ - wydajność pracy na jednego zatrudnionego w tys. USD (OECD),

2) $X_{2}$ - średni wzrost wydajności pracy w procentach (OECD),

3) $X_{3}$ - wysokość płacy minimalnej w USD (ILO),

4) $X_{4}-$ miejsce $w$ rankingu „Doing Business” (Bank Światowy),

5) $X_{5}$ - wartość Indeksu Wolności Gospodarczej (Heritage Foundation),

6) $X_{6}-$ miejsce $w$ ranking Global Competitiveness Index (World Economic Forum),

7) $X_{7}$ - wartość miernika Global Innovation Index (INSEAD i World Intellectual Property Organization),

38 AT Kearney, op.cit.

39 Sposób postępowania w badaniu oparto na opracowaniu: J. Pociecha, B. Podolec, A. Sokołowski, K. Zając, Metody taksonomiczne w badaniach społeczno-ekonomicznych, PWN, Warszawa 1998. 
8) $\mathrm{X}_{8}$ - miejsce $\mathrm{w}$ rankingu Wskaźnika Percepcji Korupcji (Transparency International),

9) $\mathrm{X}_{9}$ - wartość miernika Ibrahim Index African Governance (Mo Ibrahim Foundation),

10) $X_{10}$ - wartość Wská́nika Rozwoju Społecznego (UNDP).

Badanie oparto na danych instytucji konstruujących powyższe wskaźniki (informacje w nawiasach), natomiast wielkości płacy minimalnej pochodzą z danych ILO, a dane o wydajności pracy i jej dynamiki zaczerpnięto z baz OECD. Wszystkie statystyki dotyczą roku 2014. Wyjątek stanowi wzrost płacy minimalnej, który jest uśrednioną wartością z lat 2011-2014. Przedmiotem badania są państwa Afryki Zachodniej. W analizie taksonomicznej pomięto trzy kraje regionu - Gwineę Bissau, Niger i Togo, co wynikało z braku kompletnych danych statystycznych dla przyjętego okresu badawczego. Wszystkie wyjściowe zmienne uwzględnione w analizie znajdują się $\mathrm{z}$ aneksie.

Chociaz $w$ analizie uwzględniono tylko 10 zmiennych diagnostycznych, to należy wziąć pod uwagę znaczną ilość informacji, jakie w sobie zawierają. Wiele z nich uwzględnia cały zestaw innych, szczegółowych miar, które kompleksowo charakteryzują klimat prowadzenia działalności gospodarczej w krajach zachodnioafrykańskich.

Przy arbitralnym doborze zmiennych obrazujących potencjał gospodarczy i zaawansowanie otoczenia prowadzenia biznesu $w$ analizowanych krajach kierowano się trzema wytycznymi. Po pierwsze, wybrano ważne z punktu widzenia warunków prowadzenia działalności gospodarczej zmienne diagnostyczne, które łącznie, w miarę możliwości, będą charakteryzowały zakres badanej sfery (w tym przypadku klimat prowadzenia biznesu). Po drugie, starano się dobierać zmienne w taki sposób, aby pozostawały w miarę możliwości rozłączne. Niestety, spełnienie tego wymogu jest dość trudne, szczególnie przy analizie zjawisk opartych na wielowymiarowych indeksach, często o charakterze jakościowym. Oznacza to, że niektóre zmienne zaproponowane do badania są skorelowane, co mogło mieć wpływ na wyniki badania. Przykładem zmiennych niosących podobne informacje byly m.in. Global Competitiveness Index oraz miejsce w rankingu Banku Światowego „Doing Business". Po trzecie, starano się zachować proporcjonalność w zmiennych obrazujących poziom rozwoju klimatu prowadzenia działalności gospodarczej, czyli przyjęto, ze poszczególne zmienne mają takie same wagi.

Zasadniczą barierą w badaniu państw zachodnioafrykańskich (co odnosi się również do pozostałych krajów kontynentu afrykańskiego) pozostaje dostępność danych statystycznych. Ze względu na brak niektórych wskaźników decydujących o konkurencyjności dla niektórych analizowanych państw należało pominąć te cechy w badaniu. Wśród nieuwzględnionych wskaźników znalazły się m.in. KEI opracowywany 
przez Bank Światowy, ratingi opracowywane przez międzynarodowe agencje, wskaźnik międzynarodowej konkurencyjności czy stopa zwrotu $z$ inwestycji.

W wielowymiarowej analizie niezwykle ważną kwestią pozostaje ujednolicenie poziomu zmienności lub zakresu zmienności badanych cech. Zmienne o wysokich wartościach charakteryzują się większym wpływem na odległość pomiędzy obiektami niż zmienne o wartościach niższych. Ponadto wskaźniki cząstkowe poszczególnych aspektów potencjału wyrażone są w różnych jednostkach miary (m.in. procentowo, wartościowo) oraz charakteryzują się różnymi przedziałami zmienności. Dlatego ich bezpośrednia agregacja do postaci syntetycznej miary okazuje się niemożliwa. Stąd, aby umożliwić porównanie tych wskaźników oraz umożliwić wykonywanie na nich operacji arytmetycznych, niezbędnych do skonstruowania jednej miary, konieczna okazała się ich odpowiednia transformacja. Przekształcenie zmiennych diagnostycznych (wskaźników cząstkowych przyporządkowanych poszczególnym aspektom warunków prowadzenia działalności gospodarczej w analizowanych krajach zachodnioafrykańskich) obejmuje: stymulację zmiennych, ich normalizację oraz w przypadku ujemnych wartości cech diagnostycznych dodatkową transformację. Rezultatem dokonanych przekształceń jest uzyskanie zestawu zmiennych spełniających warunki: jednolitej preferencji, addytywności, stałości rozstępu i nieujemności.

W procesie stymulacji zmiennych dochodzi do przekształcenia różnicowego nominant i destymulant w stymulanty. Transformacja tego typu okazuje się niezbędna ze względu na fakt, iż poszczególne zmienne diagnostyczne mogą w odmienny sposób oddziaływać na badane zjawisko. Formuły dokonywanych przekształceń można przeprowadzić $w$ postaci ilorazowego przekształcenia, jednak $w$ artykule posłużono się przekształceniem różnicowym:

$$
x_{i j}^{s}=a-b x_{i j}, \quad b>0
$$

gdzie:

$a, b$ - stałe przyjmowane w sposób arbitralny, najczęściej $b=1$ i $a=0 \operatorname{lub} a=\max _{i}\left\{x_{i j}^{D}\right\}$.

$$
x_{i j}^{s}=-\left|x_{i j}^{N}-x_{j}^{N}\right|
$$

gdzie:

$x_{j}$ - nominalna (pożądana) wartość $j$-tej zmiennej,

$x_{i j}$ - wartość $j$-tej nominanty w $i$-tym obiekcie. 
W pierwszym etapie należało znormalizować zmienne zgodnie z formułą:

$$
z_{i j}=\left(\frac{x_{i j}-a}{b}\right), i=1,2, \ldots, n ; j=1,2, \ldots, m ; b \neq 0
$$

gdzie:

$z_{i j}$ - znormalizowana wartość j-tej zmiennej w $i$-tym obiekcie,

$a, b, p$ - parametry normalizacyjne.

W badaniu zastosowano trzy typy standaryzacji: standaryzację klasyczną, standaryzację średnią i standaryzację rozstępem.

1) Przeprowadzając standaryzację klasyczną, skorzystano $z$ następującej formuły normalizacyjnej:

$$
z_{i j}=\frac{x_{i j}-\bar{x}_{j}}{S\left(x_{j}\right)}, \quad i=1,2, \ldots, n ; j=1,2, \ldots, m
$$

2) W przypadku standaryzacji średnią zastosowano następującą formułę:

$$
z_{i j}=\frac{x_{i j}}{\left(\bar{x}_{j}\right)}
$$

3) Z kolei chcąc uzyskać zmienne o ujednolicony m zakresie zmienności, definiowanym przez różnicę pomiędzy ich wartościami maksymalnymi i minimalnymi w ujęciu klasycznym, zastosowano tzw. standaryzację rozstępem. W wyniku zastosowania poniższej formuły normalizacji otrzymano zmienne o wartościach należących do przedziału $[0 ; 1]$ :

$$
z_{i j}=\frac{x_{i j}-\min _{i}\left\{x_{i j}\right\}}{\max _{i}\left\{x_{i j}\right\}-\min _{i}\left\{x_{i j}\right\}}, \quad i=1,2, \ldots, n ; j=1,2, \ldots, m
$$

Po znormalizowaniu danych i eliminacji wartości ujemnych uszeregowano je zgodnie $z$ formułą standaryzacyjną:

$$
z_{i j}=h \quad \text { dla } \quad x_{h j}=x_{i}, h, i=1,2, \ldots, n
$$

gdzie:

$h$ - ranga nadana $i$-temu obiektowi znajdującemu się na $h$-tym miejscu w uporządkowanym szeregu obiektów ze względu na j-tą zmienną. 


\section{Rezultaty badania}

Na podstawie przeprowadzonych analiz empirycznych $z$ zastosowaniem trzech wybranych metod taksonomicznych sporządzono ranking państw Afryki Zachodniej pod względem warunków prowadzenia biznesu w regionie (tabela 1). Wyznaczone syntetyczne miary uporządkowały kraje zachodnioafrykańskie ( $z$ wyjątkiem Nigru, Gwinei-Bissau i Togo) w kolejności począwszy od tych, które charakteryzują się najkorzystniejszymi warunkami prowadzenia biznesu, do państw najmniej atrakcyjnych dla nawiązywania potencjalnej współpracy gospodarczej.

Rezultaty przeprowadzonego badania (tabela 1) pozwalają stwierdzić, że najbardziej sprzyjającym klimatem prowadzenia biznesu bez względu na rodzaj standaryzacji charakteryzuje się Republika Zielonego Przylądka. Kraj w większości badanych wskaźników wchodzących w skład zmiennych diagnostycznych (poza indeksem „Doing Business” i Global Competitiveness Index) uplasował się na najwyższych pozycjach spośród analizowanych państw. Na tle pozostałych krajów regionu szczególnie wysoko oceniono poziom opieki zdrowotnej i edukacji, rozwój instytucjonalny, egzekwowanie kontraktów czy wydajność pracy. Należy jednak mieć na uwadze, iż gospodarka Republiki Zielonego Przylądka jest niewielka (niski poziom PKB), a jej oddziaływanie na gospodarkę regionu i świata pozostaje bardzo ograniczone; nieznaczny jest poziom wymiany handlowej i niewielkie przepływy kapitałowe (rynek finansowy, turystyka) oraz niewielki ich udział w PKB kraju. Rozwój kraju napędzają głównie inwestycje w działalność związaną z turystyką oraz przychody z usług turystycznych i finansowych. Pozostałe gałęzie (rolnictwo: 7,4\% udział w PKB kraju, przemysł: 16,4\%) w niewielkim stopniu przyczyniają się do intensyfikacji rozwoju.

Ostatnio obserwuje się w Republice Zielonego Przylądka niekorzystnie kształtujące się tendencje rozwojowe. Chociaż państwo nie boryka się z nadmierną korupcją, rosną jednak nierówności w podziale dochodów w społeczeństwie. W ostatnich latach zauwazalny jest spadek pozycji kraju w wielu rankingach. Równiez bardzo szybko maleje wydajność siły roboczej. Kraj zmaga się z problemami wysokiego bezrobocia i głębokiego deficytu budzetowego oraz mało efektywnej polityki gospodarczej. Republika Zielonego Przylądka zaliczana jest do grupy państw o gospodarce w większości pozbawionej wolności. Stąd chociaż znalazła się na pierwszej pozycji w sporządzonych trzech rankingach, to kooperacja zagranicznego partnera $\mathrm{z}$ nim będzie miała raczej charakter incydentalny niż stały, co obrazują wahania w przepływach handlowych i kapitałowych między krajem a światem oraz poziom otwartości gospodarki. Ponadto należy pamiętać, iż państwo zaliczone zostało przez niektóre organizacje do rajów podatkowych (np. IMF), a spore uzależnienie od zagranicznej 
pomocy i inwestycji zagranicznych powoduje, iż Republika Zielonego Przylądka pozostaje podatna na szoki zewnętrzne.

Drugim ważnym dla potencjalnego zagranicznego partnera krajem w badanym regionie Afryki Zachodniej pozostaje Ghana. Państwo zostało ocenione najlepiej w regionie pod względem „Doing Business" i Global Competitiveness Index, czyli tych mierników, w których Republika Zielonego Przylądka nie osiągnęła pozycji lidera. Ghana w porównaniu z Republiką Zielonego Przylądka jest krajem o 20-krotnie większej gospodarce oraz nieporównywalnie ściślejszych i intensywniejszych powiązaniach handlowych i kapitałowych ze światem. Chociaż gospodarka Ghany oceniana jest jako w większości pozbawiona wolności, nie stoi to na przeszkodzie intensywnej współpracy międzynarodowej. Kraj relatywnie do innych państw regionu jest dobrze oceniany pod względem zaawansowania technologicznego (wysokie miejsce w subindeksie Global Competitiveness Index, KEI czy Global Innovation Index), możliwości finansowania biznesu czy wydajności siły roboczej i tempa jej wzrostu. Ghanę można scharakteryzować jako kraj wprowadzający strategię rozwoju koncentrującą się na podnoszeniu konkurencyjności oraz stabilizującą elementy instytucjonalne systemu ekonomicznego. Ponadto dywersyfikacja gospodarki Ghany oraz relatywnie dobre parametry makroekonomiczne i społeczne świadczą o możliwości nawiązania długotrwałych i korzystnych relacji ekonomicznych z tym państwem. W ostatnich latach obserwuje się wysokie tempo urbanizacji, a konsekwentnie wprowadzane reformy fiskalne i monetarne skutecznie eliminują nadmierny deficyt budżetowy, zadłużenie publiczne i wysoką inflację. Spory deficyt na rachunku obrotów bieżących Ghany wynikał głównie z niekorzystnie kształtujących się cen ropy naftowej i złota na rynku światowym, a należy pamiętać, iż produkty te stanowią ważne pozycje w eksporcie Ghany. Ponadto stopniowo rozwiązywane są problemy związane $z$ kryzysem energetycznym, $z$ którymi kraj boryka się od kilku lat. Wyzwaniami, z którymi w najbliższym czasie powinien zmierzyć się kraj, pozostają korupcja, mało zaawansowane środowisko makroekonomiczne, niski poziom edukacji i ochrony zdrowia, skomplikowane procedury handlowe czy procedury związane $z$ postępowaniem upadłościowym.

Na trzeciej pozycji we wszystkich standaryzacjach uplasował się Senegal. Chociaż gospodarka Senegalu pozostaje mniejsza od Ghany, to kraj szybko się rozwija, nadrabia zacofanie i buduje zrównoważoną oraz konkurencyjną gospodarkę. Senegal nie znalazł się na czele listy w żadnej ze zmiennych diagnostycznych uwzględnionych w badaniu, cechuje się jednak relatywnie dobrymi podstawami dla rozwoju gospodarczego. Senegal charakteryzuje najwyższe wśród omawianych krajów zaawansowanie technologiczne gospodarki (porównywalne z Ghaną) oraz wysoki poziom rozwoju instytucjonalnego na tle regionu. Czynniki te aktywnie 
wspomagają prowadzenie biznesu i osiąganie dość wysokich stóp zwrotu z zainwestowanego kapitału. O intensywnej kooperacji Senegalu ze światem świadczą wskaźniki otwarcia gospodarki. Niższe pozycje Senegalu od Ghany i Republiki Zielonego Przylądka w uwzględnionych zmiennych diagnostycznych wynikają głównie z dość niskiej oceny systemu podatkowego, słabej infrastruktury dostaw energii czy niekorzystnej ewaluacji systemu ochrony zdrowia i edukacji. Senegal charakteryzuje zbliżony do Ghany poziom korupcji oraz wolności gospodarki. Dobre perspektywy rozwojowe dla Senegalu kreśli wprowadzany plan Emerging Senegal Plan (Plan Sénégal émergent), który koncentruje się na trzech filarach: transformacji gospodarki ku nowoczesnym gałęziom, poprawie dobrobytu społeczeństwa oraz poziomu bezpieczeństwa. Ponadto polityka finansów publicznych kraju zmierza ku kompatybilności z zasadami promowanymi przez West African Economic and Monetary Union, a postępujące procesy urbanizacji stwarzają bardzo korzystne warunki do dywersyfikacji gospodarki. Wszystkie te działania zmierzają do stworzenia z Senegalu „bramy do Afryki Zachodniej”.

Dość nisko w rankingach znalazła się największa gospodarka Afryki Zachodniej - Nigeria. W standaryzacji średnią i klasycznej uplasowała się na szóstej pozycji, natomiast w standaryzacji rozstępem znalazła się dopiero na siódmej pozycji. Nigerię należy uznać za perspektywiczną gospodarkę przede wszystkim ze względu na rozmiary, dość wysokie zaawansowanie rynku wewnętrznego czy relatywnie wysoką wydajność pracy. Bogatą w surowce gospodarkę łączą silne więzy $\mathrm{z}$ innymi rynkami afrykańskimi, co może ułatwiać zagranicznemu kontrahentowi dostęp do innych krajów regionu. W Nigerii również dość dobrze oceniany jest rynek finansowy oraz dostępność kredytów, środowisko makroekonomiczne i poziom ochrony inwestorów mniejszościowych. Jednak w żadnej $z$ wymienionych sfer kraj nie zajmuje wysokiego miejsca na świecie. Prowadzenie działalności gospodarczej w Nigerii okazuje się jednak bardzo skomplikowane i ograniczane przez niesprawny system podatkowy, bariery w handlu zagranicznym, procedury rejestracji własności, trudności w dostępie do elektryczności, niski poziom edukacji i słuzby zdrowia, słabo rozwiniętą infrastrukturę czy system instytucjonalny. Również w zestawieniach obrazujących poziom korupcji Nigeria prezentuje się bardzo niekorzystnie, nawet na tle regionu. Jednocześnie nie obserwuje się trendu wzrostowego w pozycji kraju we wskaźnikach obrazujących klimat prowadzenia biznesu, który obniża się - w wielu przypadkach państwo plasuje się na coraz niższych miejscach na świecie lub pozostaje na niezmiennych pozycjach (np. poziom wolności gospodarczej, wskaźnik rozwoju społecznego czy wskaźnik „Doing Business”). Niekorzystne tendencje obserwuje się także w szybko spadającej wydajności nigeryjskiej sily roboczej czy nadal niskiej pozycji w rankingu Globalnej Innowacyjności. 
Na przeciwnym biegunie w rankingu krajów zachodnioafrykańskich, bez względu na to, jaką metodę zastosowano, uplasowała się Gwinea. Państwo to ciągle nadrabia znaczne zaległości rozwojowe w relacji do krajów regionu. W omawianych zestawieniach znajduje się na bardzo niskich pozycjach, ponadto w wielu wskaźnikach obserwuje się tendencję spadkową w pozycji kraju w międzynarodowych zestawieniach, co oznacza, iż perspektywy dalszego rozwoju Gwinei pozostają dyskusyjne. Gwinea szczególnie niekorzystnie jest oceniana pod względem innowacyjności gospodarki, rozwoju infrastruktury oraz poziomu opieki zdrowotnej i edukacji. Również wydolność systemu podatkowego, łatwość prowadzenia wymiany handlowej z zagranicą czy procedury wydawania zezwoleń na budowę plasują kraj na jednych $z$ ostatnich pozycji na świecie.

Tabela 1. Ranking krajów Afryki Zachodniej pod względem warunków prowadzenia dzialalności gospodarczej w 2014 r.

\begin{tabular}{|c|l|r|l|c|l|}
\hline \multicolumn{2}{|l|}{ Standaryzacja średnią } & \multicolumn{2}{|c|}{ Standaryzacja rozstępem [0; 1] } & \multicolumn{2}{|c|}{ Standaryzacja klasyczna } \\
\hline rangi & & rangi & & rangi & \\
\hline 1 & Republika Zielonego Przylądka & 1 & Republika Zielonego Przylądka & 1 & Republika Zielonego Przylądka \\
\hline 2 & Ghana & 2 & Ghana & 2 & Ghana \\
\hline 3 & Senegal & 3 & Senegal & 3 & Senegal \\
\hline 4 & Benin & 4 & Benin & 4 & Benin \\
\hline 5 & Wybrzeże Kości Stoniowej & 5 & Wybrzeże Kości Stoniowej & 5 & Wybrzeże Kości Sloniowej \\
\hline 6 & Nigeria & 6 & Burkina Faso & 6 & Nigeria \\
\hline 7 & Burkina Faso & 7 & Nigeria & 7 & Burkina Faso \\
\hline 8 & Mali & 8 & Mali & 8 & Mali \\
\hline 9 & Mauretania & 9 & Gambia & 9 & Gambia \\
\hline 10 & Sierra Leone & 10 & Sierra Leone & 10 & Sierra Leone \\
\hline 11 & Gambia & 11 & Liberia & 11 & Mauretania \\
\hline 12 & Liberia & 12 & Mauretania & 12 & Liberia \\
\hline 13 & Gwinea & 13 & Gwinea & 13 & Gwinea \\
\hline
\end{tabular}

Źródło: Opracowanie i obliczenia własne.

W ostatnich latach narodowym priorytetem władz pozostaje efektywna polityka mieszkaniowa (Vision Habitat 2021), która ma być jednym ze sposobów redukcji ubóstwa i ogromnych dysproporcji rozwojowych. Kraj znajduje się w grupie państw o niskim poziomie rozwoju społecznego oraz $\mathrm{z}$ represjonowaną gospodarką, a skuteczność polityki gospodarczej władz jest niewystarczająca. Sporą odpowiedzialność za pogarszającą się i tak niekorzystną pozycję Gwinei w międzynarodowych zestawieniach ponosi epidemia wirusa eboli. Niski poziom rozwoju wewnętrznego Gwinei ma przełożenie na ograniczone kontakty gospodarcze kraju ze światem; poziom 
otwarcia kraju na świat pozostaje jednym z mniejszych wśród państw regionu, napływy inwestycji bezpośrednich są niskie, a rachunek obrotów bieżących znajduje się w chronicznym deficycie.

\section{Rekomendacje dla kierunków polityki gospodarczej oraz strategii przedsiębiorstw w stymulowaniu ekspansji na rynki krajów Afryki Zachodniej}

Na podstawie przeprowadzonych badań można sformułować wnioski i rekomendacje dla kierunków polityki gospodarczej oraz strategii przedsiębiorstw w stymulowaniu ekspansji na rynki krajów Afryki Zachodniej ${ }^{40}$.

1) Rynki krajów Afryki Zachodniej dysponują znacznym potencjałem gospodarczym i możliwościami rozwojowymi. Są to rynki dynamiczne, o rosnącej konkurencyjności oraz wysokiej dynamice wzrostu wraz z prognozami jej utrzymania. Pomimo istniejących wyzwań rozwojowych związanych z problemami ubóstwa, niskim poziomem rozwoju społecznego, nierównościami rozwojowymi, barierami o charakterze infrastrukturalnym i instytucjonalnym oraz niestabilnością polityczną i gospodarczą można je uznać za rynki perspektywiczne dla potencjalnej współpracy gospodarczej.

2) W ujęciu szczegółowym za przesłanki dla intensyfikacji współpracy gospodarczej z Afryką Zachodnią można uznać rosnące wydatki konsumpcyjne i rządowe krajów regionu, związane głównie $z$ koniecznością zapewnienia społeczeństwu podstawowych usług (elektryczności, wody, edukacji, usług medycznych, urządzeń sanitarnych); potrzeby w wymiarze infrastruktury transportowej, telekomunikacyjnej oraz bezpośrednio produkcyjnej; zapotrzebowanie tamtejszych rynków na zaawansowane technologie we wszystkich wymiarach działalności gospodarczej; potencjał demograficzny i jego strukturę, wraz z bogacącą się klasą średnią; zmieniający się charakter gospodarki światowej i możliwości włączenia się krajów w globalne lańcuchy wartości.

3) Niezbędne będą działania na szczeblach administracji rządowej poszczególnych krajów zamierzających podjąć współpracę mające na celu zbieranie informacji o rynkach Afryki Zachodniej, ich potencjale, możliwościach rozwojowych, zapo-

40 Szczególowe rekomendacje odnośnie do współpracy Polski z krajami afrykańskimi znajdują się w opracowaniu: T. Rynarzewski, K. Nawrot, K. Zajączkowski, E. Cieślik, Potencjat gospodarczy i możliwości rozwojowe Afryki. Polska perspektywa, PWE, Warszawa 2017. 
trzebowaniu, popycie konsumpcyjnym, uwarunkowaniach instytucjonalnych (m.in. barierach handlowych, systemach podatkowych), warunkach i klimacie do prowadzenia działalności gospodarczej, a także zidentyfikowanie rynków priorytetowych oraz kierunków branżowych dla potencjalnej współpracy.

4) Na podstawie przeprowadzonej analizy potencjału gospodarczego krajów Afryki Zachodniej wyróżniono następujące rynki o wysokim potencjale i możliwościach prowadzenia działalności gospodarczej: Republika Zielonego Przylądka, Ghana, Senegal. Zidentyfikowane rynki uznano za szczególnie perspektywiczne kierunki geograficzne dla współpracy gospodarczej z krajami Afryki Zachodniej.

5) Istotne jest poszukiwanie oraz określenie nisz rynkowych - co będzie wy magało dalszych badań - w których oferta europejskich podmiotów byłaby konkurencyjna i uwzględniająca zmiany, jakie zachodzą na rynkach Afryki Zachodniej w ostat nich latach, oraz perspektywy ich dalszego rozwoju. Oferowane towary i usługi powinny być w jak największym stopniu dostosowane do: specyfiki rynków afrykańskich, w szczególności trudnych warunków eksploatacyjnych, jakości infrastruktury drogowej oraz braku bądź przerw w dostawach energii elektrycznej; zmieniających się społeczeństw poszczególnych krajów, z jednej strony do bogacącej się klasy średniej, która poszukuje dobrych jakościowo towarów i usług oferowanych przez firmy europejskie, $z$ drugiej zaś do ciągle ograniczonych dochodów.

\section{Konkluzje}

Artykuł koncentruje się na taksonomicznej analizie zróżnicowania warunków prowadzenia biznesu w krajach Afryki Zachodniej. Celem badania było przeprowadzenie wielowymiarowej oceny warunków prowadzenia działalności gospodarczej i uzyskanie rankingu państw pod względem korzystności tego klimatu. Na podstawie przeprowadzonej analizy potwierdzono, że w Republice Zielonego Przylądka panują najkorzystniejsze warunki prowadzenia działalności gospodarczej, co jednak zupełnie nie przekłada się na intensywność przepływów handlowych i kapitałowych między krajem a światem. Natomiast znajdujące się na kolejnych miejscach kraje (Ghana i Senegal), chociaż nie generują największej produkcji czy przepływów kapitałowych i handlowych w regionie, zdają się wykorzystywać swoją dynamicznie poprawiającą się sytuację gospodarczą i intensyfikują procesy internacjonalizacji. Na wysokie pozycje krajów w rankingu mają także wpływ wszelkie czynniki prowadzące do utrzymania wewnętrznej stabilności. Dość nisko w zestawieniu uplasowała się 
Nigeria, w której poza nielicznymi wymiarami prowadzenia działalności gospodarczej pozytywnie ocenionymi większość wskazuje na nadal znaczne zacofanie kraju pod względem klimatu prowadzenia biznesu w porównaniu z innymi gospodarkami.

Zaprezentowane wyniki badania posiadają walory aplikacyjne w kontekście wniosków i rekomendacji dla kierunków polityki gospodarczej państw europejskich oraz strategii przedsiębiorstw w stymulowaniu ekspansji na rynki państw Afryki Zachodniej. Współcześnie kontynentem afrykańskim interesują się przedsiębiorcy z całego świata. Należy się spodziewać, że również w Polsce będą konstruowane programy czy powoływane instytucje mające przybliżyć zasady funkcjonowania biznesu w Afryce. Stąd zasadna wydaje się kontynuacja badań i wskazywanie krajów perspektywicznych dla długoterminowej współpracy.

Należy jednak mieć na względzie ograniczenia przeprowadzonego badania, wynikające chociażby z trudności dostępu do najnowszych danych dla wszystkich omawianych państw regionu zachodnioafrykańskiego. Ponadto zasadne byłoby przeprowadzenie analizy dynamicznej. Dlatego podobne badanie powinno zostać powtórzone w kolejnych latach, gdyż ukazałoby kierunki zmian w warunkach prowadzenia biznesu $w$ analizowanych krajach. 


\begin{tabular}{|c|c|c|c|c|c|c|c|c|c|c|c|c|c|}
\hline \multirow{15}{*}{ 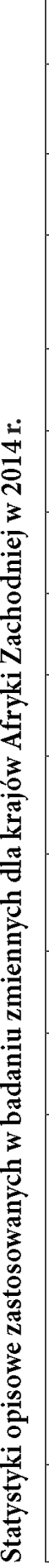 } & 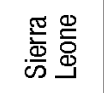 & $\frac{\infty}{s}$ & $\begin{array}{l}\text { "ू } \\
10\end{array}$ & 高 & f & $\frac{1}{i n}$ & & & & 5 & & & \\
\hline & 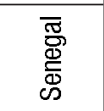 & i̊ & $\begin{array}{l}0 \\
i \\
i p\end{array}$ & 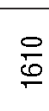 & $\Phi$ & $\overbrace{i}^{\infty}$ & & & & ? & छ & & \\
\hline & $\begin{array}{l}\frac{\pi}{\overline{\underline{N}}} \\
\frac{\mathrm{O}}{2}\end{array}$ & $\underset{i=j}{\bar{N}}$ & $\frac{1}{1}$ & 兽 & $\stackrel{?}{I}$ & 点 & & & & v & & & \\
\hline & 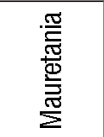 & 总 & $\overline{i p}$ & 잉 & $\stackrel{\varrho}{!}$ & Di & & & & $b$ & ร & & \\
\hline & $\frac{\overline{\bar{\pi}}}{\overline{2}}$ & $\underset{\substack{\sim \\
\sim}}{ }$ & $\frac{g}{\sigma}$ & $\frac{N}{10}$ & of & $\mid \begin{array}{l}7 \\
0 \\
0\end{array}$ & & & o. & $\vec{b}$ & $\stackrel{\infty}{7}$ & & \\
\hline & 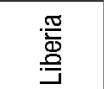 & $\stackrel{g}{\circ}$ & $\bar{c}$ & న్ & $\stackrel{ \pm}{ \pm}$ & స్ & & & & a & & & \\
\hline & 怘 & 祭 & ্ָ & 寺 & 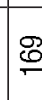 & is & & & & s. & ฯ & & \\
\hline & 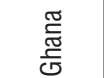 & 栗 & $\overline{50}$ & 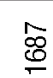 & 尺 & 8 & & & 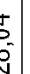 & of & & & \\
\hline & 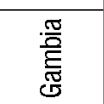 & $\stackrel{0}{=}$ & $\underset{\forall}{\sim}$ & $\stackrel{g}{\stackrel{\rho}{\varrho}}$ & $\stackrel{\infty}{\stackrel{\infty}{?}}$ & 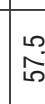 & & & is & S & & & \\
\hline & 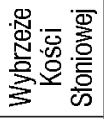 & 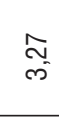 & $\begin{array}{l}\text { co }^{\infty} \\
\infty^{-1}\end{array}$ & 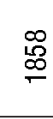 & 于 & {$\left[\begin{array}{l}1 \\
0 \\
\infty \\
10\end{array}\right.$} & & & $=0$ & $\vec{b}$ & & & \\
\hline & 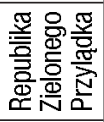 & : & דَ & $\stackrel{N}{\stackrel{N}{N}}$ & & $\begin{array}{l}7 \\
0 \\
0\end{array}$ & & & & 6 & & & \\
\hline & 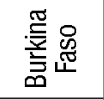 & $\stackrel{\forall}{\stackrel{f}{-}}$ & 孚 & $\begin{array}{l}\mathbb{R} \\
\stackrel{\infty}{C}\end{array}$ & ب̂ & {$\left[\begin{array}{l}0 \\
0 \\
0 \\
0\end{array}\right.$} & & & . & : & & & \\
\hline & 誉 & 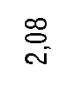 & $\stackrel{5}{E}$ & $\stackrel{\widetilde{D}}{\mathrm{~N}}$ & in & {$\left[\begin{array}{l}\infty \\
\infty \\
\infty \\
i\end{array}\right.$} & & & 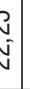 & 召 & & & \\
\hline & 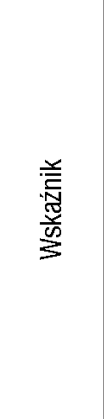 & 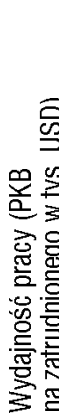 & 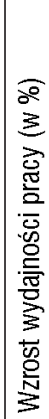 & 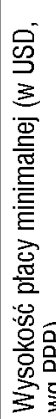 & 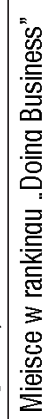 & 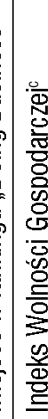 & & & 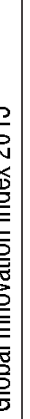 & 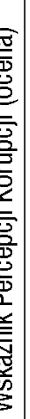 & & & \\
\hline & 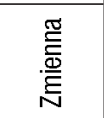 & $\bar{x}$ & $x^{2}$ & $x^{\infty}$ & $x^{2}$ & $+\infty$ & & & $\times 1$ & & & & \\
\hline
\end{tabular}




\section{Literatura}

AfDB et al., African Economic Outlook 2015. Regional development and spatial inclusion, OECD Publ., Paris 2015.

African Union, 2015, http://www.au.int/

AT Kearney, FDI Confidence Index, 2015, https://www.atkearney.com/

CIA Factbook, 2015, https://www.cia.gov/library/publications/resources/the-world-factbook/

Cieślik E., African Sovereign Wealth Funds: Facts and figures, „Gospodarka Narodowa” Iss. 6, 2014.

Cleveland H., Youth unemployment in West Africa, „Borgen Magazine” 16, 2014.

Global Economy and Development at Brookings, 2015, Private capital flows, official development assistance, and remittances to Africa: Who gets what?

Heritage Foundation, 2015, http://www.heritage.org

Ibrahim Forum, 2013 Ibrahim Forum Facts \& Figures, Africa ahead: The next 50 years, Mo Ibrahim Forum Foundation, Addis Abeba, November 2013.

IFC, The World Bank, Doing Business Report 2014, Washington, D.C. 2014.

ILO, 2015, http://www.ilo.org/global/lang--en/index.htm

Johnson Cornel University, INSEAD, WIPO, The Global Innovation Index 2015.

OECD, International direct investment database, 2015, http://stats.oecd.org/

OECD, OECD Statistics, 2015, http://stats.oecd.org/

Pociecha J., Podolec B., Sokołowski A., Zając K., Metody taksonomiczne w badaniach spoteczno-ekonomicznych, PWN, Warszawa 1998.

Population Reference Bureau, 2013 World Population Data Sheet, 2015, http://www.prb. org/Publications/Datasheets/2013/2013-world-population-data-sheet/world-map. aspx\%23map/world/population/2013

Rynarzewski T., Nawrot K., Zajączkowski K., Cieślik E., Potencjał gospodarczy i możliwości rozwojowe Afryki. Polska perspektywa, PWE, Warszawa 2017.

Seck D., Accelerated economic growth in West Africa, Springer, Dakar 2015.

SWF Institute, 2015, http://www.swfinstitute.org/

Transparency International, 2015, http://www.transparency.org/cpi2014/results

UNCTAD, UNCTAD Database, 2016, www.unctad.org

UNDP, Human Development Reports, 2015, http://hdr.undp.org/en/2015-report

USAID, EADS Economic Trends Reports: West Africa, 2013.

U.S. Geological Survey, 2015, http://www.usgs.gov/

WDI, World Development Indicators, World Bank Database, 2015.

WEF, 2015, http://www.weforum.org/ 
World Bank, World Bank Database, 2015.

World Bank, IBRD, IDA, The World Bank Data, 2015, http://data.worldbank.org/indicator World Integrated Trade Solutions, 2015, http://wits.worldbank.org

\section{Economic Potential of West Africa: Selected Policy Implications from Taxonomic Analysis}

The article attempts to assess the economic potential of West Africa, using the taxonomic methods, formulate policy recommendations, and identify potential geographic directions of cooperation with the West African countries. It consists of four sections. The first part of the article characterizes the economies of West Africa in terms of their economic potential. The second section presents research methods and data applied in taxonomic analysis. Part three of the article discusses the results of taxonomic analysis. In the last part of the article we attempted to formulate recommendations for the economic policy of European countries and the strategies of European enterprises in stimulating expansion in the West African countries.

Keywords: West Africa, economic cooperation, economic potential JEL classification: B23, F50, N17

\section{Potentiel économique de l'Afrique de l'Ouest: implications choisies de l'analyse taxonomique pour l'expansion économique}

Les marchés de l'Afrique de l'Ouest sont récemment devenus le centre d'intérêt croissant des pays développés, y compris de tous les pays européens. Un grand nombre d'entrepreneurs voient un potentiel immense et inexploité de la région. Les relations commerciales et les flux de capitaux entre l'Afrique de l'Ouest et le monde restent marginaux, mais on peut s'attendre à un développement dynamique dans les années à venir.

Les objectifs de ce texte sont:

1) l'évaluation du potentiel économique de l'Afrique de l'Ouest à l'aide de méthodes taxonomiques;

2) la formulation des recommandations politiques et la définition des orientations géographiques potentielles de la coopération avec les pays d'Afrique de l'Ouest. 
Larticle est composé de quatre parties. La première décrit les économies de l'Afrique de l'Ouest en termes de leur potentiel économique. La deuxième contient une description de la méthode de recherche appliquée ainsi qu'une description des données utilisées dans l'analyse taxonomique. La troisième partie de l'article présente les résultats de l'analyse taxonomique. La dernière partie est une tentative pour formuler des indications et des recommandations concernant la politique économique des pays européens et les stratégies des entreprises européennes visant à accroître l'expansion sur les marchés de l’Afrique de l'Ouest.

Mots-clés: Afrique de l'Ouest, coopération économique, potentiel économique La classification JEL: B23, F50, N17

\section{Экономический потенциал Западной Африки: избранные рекомендации, вытекающие из таксономического анализа}

В последнее время западноафриканские рынки вызывают растущий интерес со стороны развитых страп, включая все европейские государства. Многие предприниматели признают огромный и одновременно неиспользованшый потенциал региона. Торговые отношения и потоки капитала между Западной Африкой и остальным миром являются незнатительными, но в ближайшие годы можно ожидать динамичного развития экономического сотрудничества.

Целями статьи являются:

1) оценка экономического потенциала Западной Африки при использовании таксономических методов;

2) формулирование политических рекомендаций и определение потенциалынх географических паправлений сотрудничества с западноафриканскими странами.

Статья состоит из четырех частей. В первой части характеризуются экономики Западной Африки с точки зрения их экономического потенциала. Во второй представлен метод исследования и даншые, применяемые в таксономическом анализе. В третьей части обсуждаются результаты таксономического анализа. В последней части статьи делается попытка сформулировать рекомендации по экономическому развитию западноафриканских стран.

Ключевые слова: Западная Африка, экономическое сотрудничество, экономический потенциил

Классификация JEL: B23, F50, N17 